\title{
Mapping anthropogenic $B(a) P$ releases in the Great Lakes Basin
}

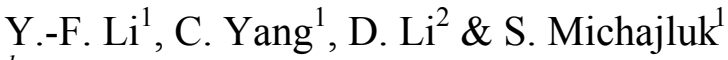 \\ ${ }^{1}$ Environment Canada, Toronto, Canada \\ ${ }^{2}$ LDC Consulting, Toronto, Canada
}

\begin{abstract}
Benzo(a)pyrene $(\mathrm{BaP})$ is one of the most toxic PAHs. It is listed as a priority toxic substance with a target for virtual elimination under the Great Lakes Bi-national Toxics Strategy (GLBTS). At the GLBTS's meeting in December 2005, BaP monitoring data of both Canada and U.S.A. shows that ambient BaP concentrations at urban sites are 10 times higher than those in rural sites, reflecting a significant local source contribution. This paper is prepared to (1) Map the local releases in nine province/states of the Great Lakes Basin (2) Analyze sources of $\mathrm{BaP}$ in high-releasing regions (3) Map ambient air monitoring data in the Basin. The $\mathrm{BaP}$ inventories used for the mapping originated from USEPA's 1999 National Emissions Inventory (NEI) and Environment Canada's Ontario inventory 2003. Approximately 27,000 kg of $\mathrm{BaP}$ releasing from the Basin's anthropogenic sources were mapped, with $30 \%$ from Ontario, Canada and $70 \%$ from the eight states in the U.S. The Basin is divided into 280 grid cells (each $100 \mathrm{~km} \times 100 \mathrm{~km}$ ) using a high-resolution GIS mapping tool. It is found that five grid cells with releases in 1,000-2,000 kg/year are the highest relative to the others in $10-1,000 \mathrm{~kg} / \mathrm{y}$. They are located in Ontario, Ohio, Illinois, and Indiana. This agrees well with the higher ambient $\mathrm{BaP}$ concentrations detected in the Chicago, Hamilton, and Toronto areas in these province/states in the past 15 years. The 2003 annual averages were 500, $300,200 \mathrm{pg} / \mathrm{m}^{3}$ for these three cities, respectively. The common source sectors of $\mathrm{BaP}$ in both countries are steel manufacturing, residential wood combustion, scrap tire burning, the use of creosote railway ties, primary metals production, household waste burning, and motor vehicles.

Keywords: Policyclic Aromatic Hydrocarbons (PAHs), Benzo(a)pyrene (BaP), Great Lakes Binational Toxics Strategy (GLBTS), emission inventory, Great Lakes Basin, mapping, release, ambient air monitoring.
\end{abstract}




\section{Introduction}

The paper is prepared to improve the understanding of $\mathrm{BaP}$ releases to the environment and to address some issues raised by the $\mathrm{BaP}$ management assessment of the Great Lakes Binational Toxics Strategy (GLBTS) [1]. This paper maps annual $\mathrm{BaP}$ releases from each county/municipality in nine states/province, which locates the $\mathrm{BaP}$ high-releasing areas and the ambient air concentrations in the GL Basin. The information is useful in identifying locations and specific sources to help take actions towards $\mathrm{BaP}$ reduction and ambient air quality improvement.

High-resolution GIS mapping tools are used to map annual release of $\mathrm{BaP}$ in the GL Basin in 2003. Majority of BaP was released to air with few to soil, and water. The 1999 NEI data were directly provided by USEPA [2]. The Ontario 2003 inventory is developed by Environment Canada that is used to support the GLBTS [3]. The U.S. and Ontario data are reviewed to ensure the source sectors are comparable, but the estimation methodologies for each source sector are not reviewed. Due to the unavailability of the 2003 NEI data at the time of this mapping work was undertaken, it is assumed 1999 NEI inventory reflects the level of BaP releases in 2003 in the U.S. states.

\section{The Great Lakes Basin: area and population}

The GL Basin includes the five Great Lakes, the eight states of U.S.A. and Ontario province of Canada. The area and population of each state/province is summarized in Figures 1 and 2. The area size of Ontario $\left(1,076,395 \mathrm{~km}^{2}\right)$ in Canada is as large as the total of the eight states $\left(1,073,815 \mathrm{~km}^{2}\right)$, while Ontario population $(12,256,645)$ is only $15 \%$ of the total of the eight states in the U.S.A $(82,892,648)$.

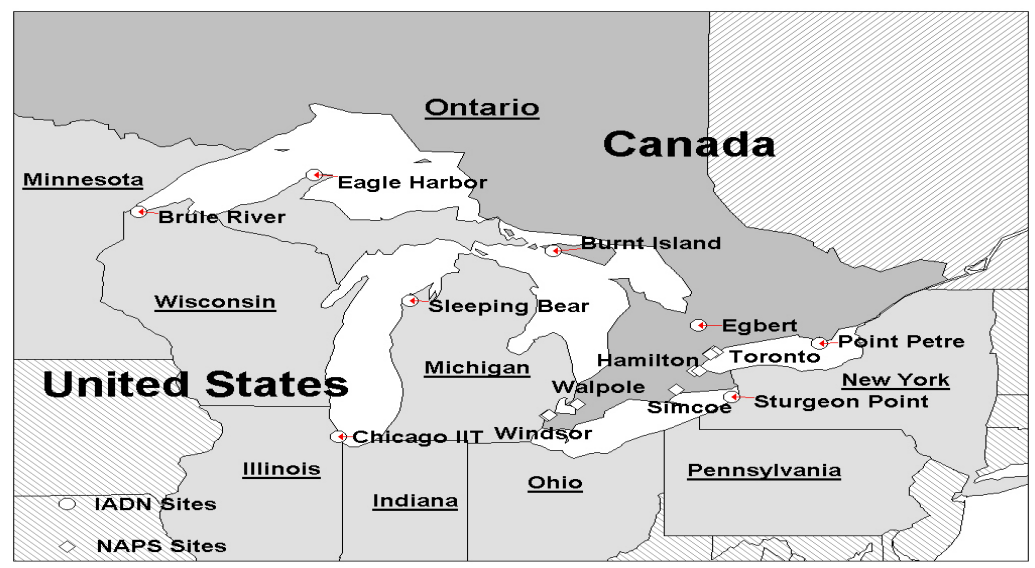

Figure 1: Nine States/Province and Five Great Lakes in the Great Lakes Basin. 


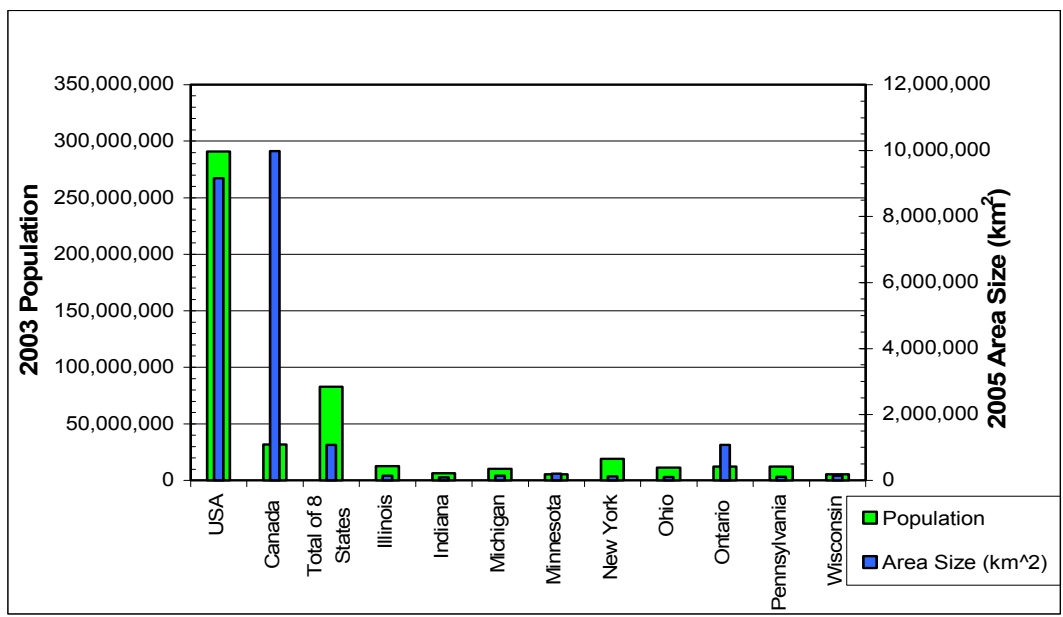

Figure 2: 2003 Population and 2005 area size of the Great Lakes States/Province [4,5].

\section{BaP Releases in the Great Lakes Basin}

The $2003 \mathrm{BaP}$ releases are plotted in Figure 3. 8,400 $\mathrm{kg}$ and 18,500 $\mathrm{kg}$ of BaP were released from Ontario and the eight states respectively, which makes a total release of $27,000 \mathrm{~kg}$ to air, soil, and water Basin-widely with majority to the air. The contributions from each source sector in Ontario of Canada and the eight states of U.S. are described separately below.

For the 2003 Ontario BaP inventory of $8,400 \mathrm{~kg}$, the population and spacial intensity is $0.6 \mathrm{~g} / \mathrm{capita} /$ year or $8 \mathrm{~g} / \mathrm{km}^{2} / \mathrm{yr}$. $65 \%$ came from non-point sources, $25 \%$ from point sources, and 10\% from mobile sources. The major source sectors are the use of creosote railway tie $(30 \%)$, residential wood combustion $(28 \%)$, iron \& steel sector $(25 \%)$, and motor vehicles $(10 \%)$ [3].

For the $18,500 \mathrm{~kg}$ of $\mathrm{BaP}$ in the eight states of the U.S.A., the population and spacial intensity is $0.2 \mathrm{~g} /$ capita/year or $17 \mathrm{~g} / \mathrm{km}^{2} / \mathrm{yr}$. They were released from a few source sectors including household waste burning (HWB), open burningscrap tire (OB-ST), residential wood combustion (RWC), Iron \& Steel (IS), petroleum refining (PR), primary non-ferrous metals (PNM), health service (HS), ferrous foundries (FF), diesel motor vehicles (DMV), and gasoline motor vehicles (GMV). 65\% came from non-point sources, $29 \%$ from point sources, $4 \%$ from on-road and $2 \%$ from non-road mobile sources. The major source sectors are residential wood combustion $(30 \%)$, household waste burning $(15 \%)$, open burning-scrap tires $(10 \%)$, primary non-ferrous metals $(8 \%)$, iron \& steel sector $(6 \%)$, and motor vehicles (4\%) [6].

The releases from non-point and point sources are significant in both countries with non-point source is twice as high. It is worthy to note that the Ontario estimates on non-point source and on-road mobile source are all 
substantially greater than those in any of the U.S. states. The difference in Ontario estimate points to a possibility in the difference of the estimation methodologies of both inventories. In addition to the benefit on identifying highreleasing areas and their source sectors, this paper helps to highlight some data gaps on the inventory development

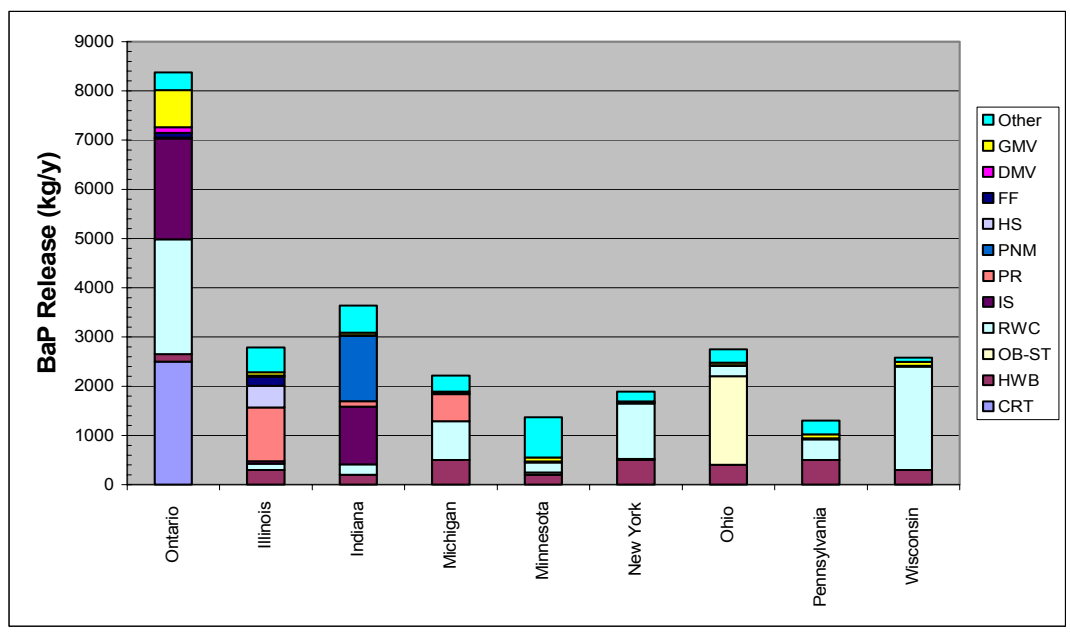

Figure 3: Releases from major source sectors in each State/Province.

\section{Mapping BaP releases in the GL Basin}

$27,000 \mathrm{~kg}$ of $\mathrm{BaP}$ releases from each counties and municipalities are mapped on a digital map. The Basin is divided into 277 grid cells (164 cells in U.S. and 113 cells in Ontario). B(a)P releases in most grid cells range from 10 to $1,000 \mathrm{~kg} / \mathrm{yr}$, refer to Figure 4. However, there are five grid cells (four of them in U.S.) have higher releases in 1,000-2,100 kg/yr from Iron \& Steel, Primary Nonferrous Metals, Petroleum Refining, Scrap Tire Burning, and Petroleum Refining. The findings are consistent with those from the county-based map (not shown). These cells are located in Toronto/Hamilton area in Ontario, Columbus area in Ohio, Chicago area in Illinois, and the other two cells located in Indiana and Illinois that are further away from the Great Lakes, see Table 1.

\section{Mapping ambient air BaP in the Great Lakes Basin}

The monitoring data from International Air Deposition Network (IADN) and National Air Pollution Surveillance (NAPS) are used to compare with the local releases of $\mathrm{BaP}$. It is found that the ambient air $\mathrm{BaP}$ is higher in the area with higher BaP releases, such as in urban cities. 


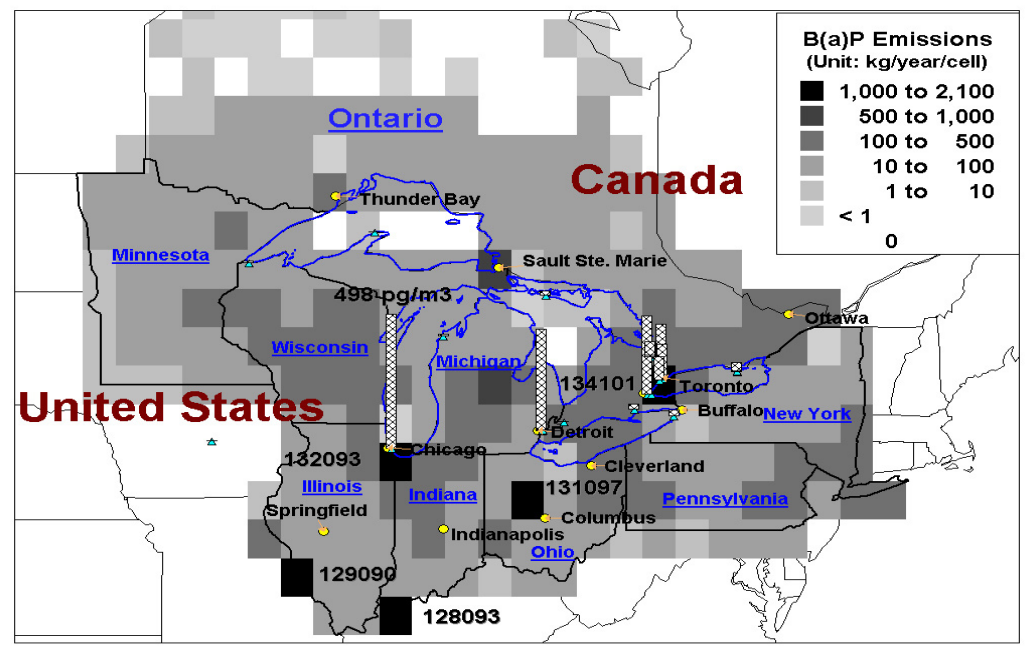

Figure 4: Gridded B(a)P Emissions in the USA (1999) and Ontario Releases (2003).

Table 1: $\quad$ Five grid cells with highest BaP releases in the Great Lakes Basin.

\begin{tabular}{|l|l|l|l|l|}
\hline $\begin{array}{l}\text { Grid } \\
\text { Cell } \\
\text { GEIA })\end{array}$ & $\begin{array}{l}\text { BaP } \\
\text { Releases } \\
(\mathrm{kg} / \mathrm{yr})\end{array}$ & Major Sources & Major City & State/Province \\
\hline 134101 & 2040 & Iron \& Steel & $\begin{array}{l}\text { Hamilton, } \\
\text { Toronto }\end{array}$ & Ontario \\
\hline 131097 & 1843 & $\begin{array}{l}\text { Open Burning - } \\
\text { Scrap Tires }\end{array}$ & Columbus & Ohio \\
\hline 132093 & 1349 & $\begin{array}{l}\text { Iron \& Steel and } \\
\text { Petroleum } \\
\text { Refining }\end{array}$ & Chicago & Illinois and Indiana \\
\hline 128093 & 1323 & $\begin{array}{l}\text { Primary } \\
\text { Nonferrous Metals }\end{array}$ & $\begin{array}{l}\text { Petroleum } \\
\text { Refining }\end{array}$ & Indiana and Kentucky \\
\hline 129090 & 1140 & & & Illinois and Missouri \\
\hline
\end{tabular}

\subsection{IADN and NAPS monitoring stations}

IADN station information is obtained from their website: http://www.msc.ec.gc.ca/iadn [7]. NAPS data were provided by ETC of Environment Canada [8]. Most of the IADN's stations are located in rural and undeveloped areas with data representative of the background ambient air for each of the five Great Lakes. NAPS has stations all over Ontario and other major cities in Canada that monitors ambient air BaP concentration in both urban and rural areas, refer to Figure 1. The analytical methods from both programs have some variations [9]. 


\subsection{Ambient BaP concentrations in 2003}

Both IADN and NAPS measure BaP in both particle and gas phases. However, almost all $\mathrm{BaP}$ is present in the particle phase at ambient temperature [10]. 2003 annual average $\mathrm{BaP}$ concentrations from IADN and NAPS are provided in Figures 4 and 5 . These are the average of numerous data points measured in an interval of every 12 days in 2003. As can be seen, local BaP releases correspond well to the ambient air BaP concentrations. This applies to almost all the monitoring stations of NAPS and IADN.

The existing monitoring data show that the highest $\mathrm{BaP}$ concentrations are identified in three regions-Chicago (498 pg/m $\mathrm{m}^{3}$ ), Hamilton/Toronto (100-300 $\left.\mathrm{pg} / \mathrm{m}^{3}\right)$, and Windsor/Detroit $\left(380 \mathrm{pg} / \mathrm{m}^{3}\right)$. Comparing the local BaP releases indicate that high $\mathrm{BaP}$ releases in both Chicago and Hamilton/Toronto areas are a significant factor leading to high ambient $\mathrm{BaP}$ concentration. The map also shows that low ambient concentrations of $\mathrm{BaP}$ might be a result of the low local $\mathrm{BaP}$ releases. The only exception is with the Windsor/Detroit site, where a higher ambient air BaP $\left(380 \mathrm{pg} / \mathrm{m}^{3}\right)$ is detected with a low annual release. This points to a need to further investigate both the air monitoring data and the BaP inventory. It is possible that some sources of $\mathrm{BaP}$ in Windsor/Detroit area were not well documented in the inventory.

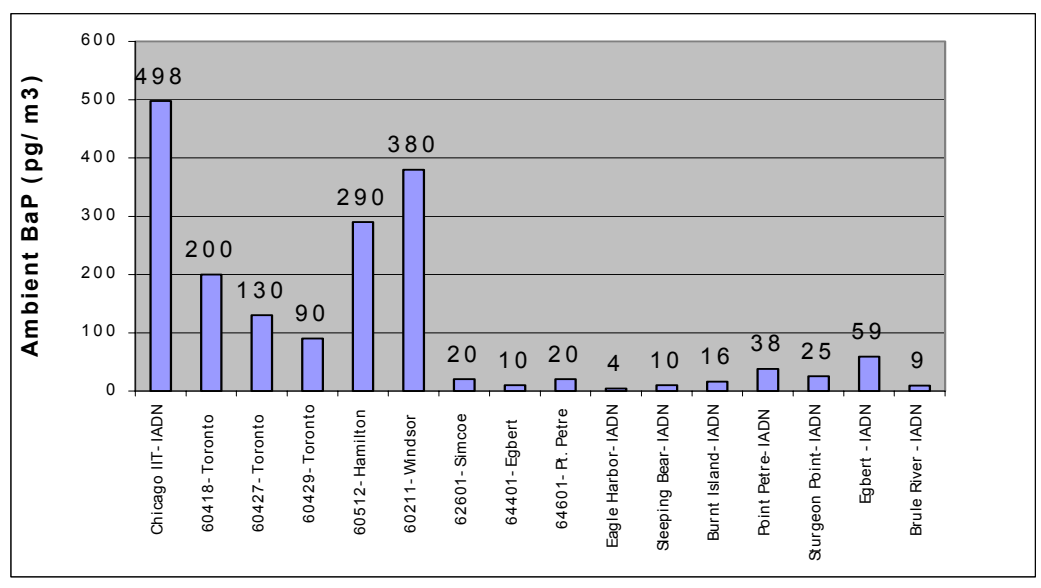

Figure 5: 2003 annual average $\mathrm{BaP}$ concentrations.

\subsection{Trending of IADN data}

The trending of IADN's BaP ambient air concentrations from 1990-2004 on six rural stations is plotted in Figure 6. These stations are located in Eagle Harbor for L. Superior, Sleeping Bear for L. Michigan, Burnt Island for L. Huron, Point Petre for L. Ontario, and Sturgeon Point for L. Erie. As shown, annual average air concentrations fluctuated with years since 1990. It does not show a clear decreasing trend. These sites are located in rural or undeveloped areas with low 
local $\mathrm{BaP}$ releases that are well below $100 \mathrm{~kg} / \mathrm{y}$ in each grid cell, refer to Figure 4 for details. The ambient BaP concentrations are slightly higher on the sites for L. Ontario and Lake Erie, which might be the result of a higher BaP release in the area.

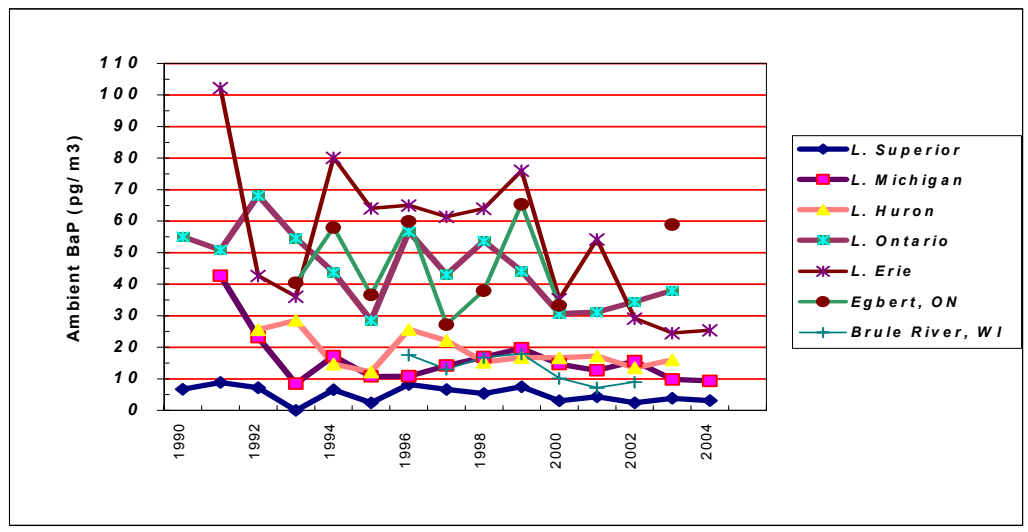

Figure 6: Trend of ambient BaP concentrations in the Great Lakes from IADN.

The BaP release data for multiple years for the grid cells in which these sites located are not available, so it is difficult to prorate the impact the local or nonlocal release has on the ambient air in these areas. It is likely that the releases in these grid cells have been very low in the past 15 years that a slight or no change in annual release did not bring a significant impact on the ambient air BaP concentration. This might explain why there is no clear decreasing trend on the monitoring data for these sites. It is not well known what size of the grid cell or spatial coverage is a good representation of a local release. However, the size of $1^{\circ}$ latitude $\times 1^{\circ}$ longitude $(100 \mathrm{~km} \times 100 \mathrm{~km})$ is used in this paper.

\subsection{Trending of NAPS data}

The NAPS's monitoring stations are located in cities and some rural areas, refer to Figure 7 for details. As aforementioned, $\mathrm{BaP}$ air pollution is a local release issue and it is believed that the monitoring sites that are located in a grid cell representative of the local release are better indicators of the local $\mathrm{BaP}$ release trending. There are four monitoring stations located in the grid cells with higher $\mathrm{BaP}$ releases, so these sites are used to track the trending of ambient $\mathrm{BaP}$ from 1995-2003. These stations are: 60418-Toronto, 60512-Hamilton, 60211Windsor from NAPS and Chicago IIT from IADN. The monitoring data are plotted in Figures 7 and 8. As shown, the ambient BaP on 12 rural and urban sites from NAPS and IADN does not show a clear trending from 95-03, which might be the result of the fluctuation of annual $\mathrm{BaP}$ releases in the vicinity of these sites. There is no obvious declining trend of $\mathrm{BaP}$ in Toronto, Windsor, Chicago, and almost all the other stations. This might be the result of no 
significant reduction of local $\mathrm{BaP}$ releases on these stations. An exception is with the Hamilton monitoring site. The station is located in the grid cell that is representative of the local $\mathrm{BaP}$ release. Its monitoring data show a declining trend of BaP in the ambient air in eight consecutive years from 1996-2003. It agrees very well with the declining trend of local $\mathrm{BaP}$ releases due to the significant reduction of $\mathrm{BaP}$ from major source sectors in that area.

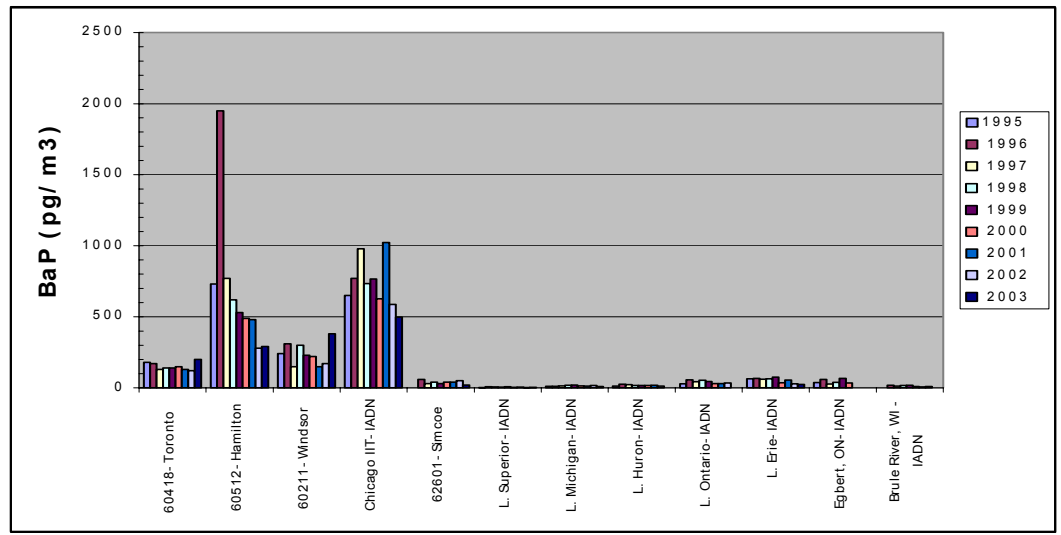

Figure 7: Annual variation of ambient $\mathrm{BaP}$ concentrations at major stations.

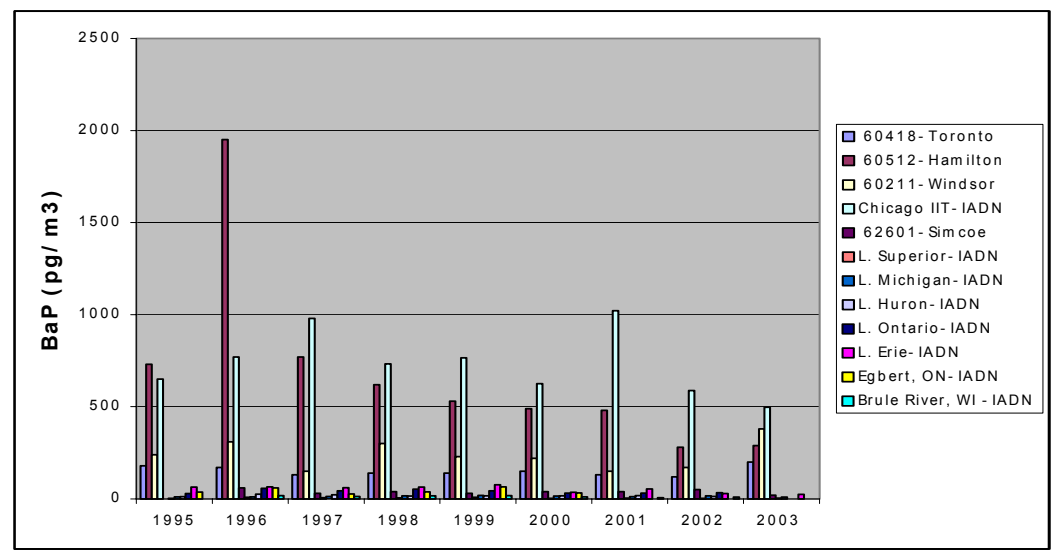

Figure 8: Annual average BaP concentrations 1995-2003.

\section{Conclusions and recommendations}

There are about $27,000 \mathrm{~kg}(59,400 \mathrm{lbs})$ of $\mathrm{BaP}$ released in 2003 in the Great Lakes Basin, of which $70 \%$ was from the U.S. and 30\% from Canada. A gridded release inventory is used in this paper to locate the $\mathrm{BaP}$ in each county/municipality of the Basin. The size of the grid cell can be chosen so that 
it is representative of the local $\mathrm{BaP}$ release for the areas of interest. The common major source sectors in both U.S. and Canada are residential wood combustion, steel manufacturing, primary metals production, scrap tire burning, household waste burning, and motor vehicles.

There are five grid cells in the Basin having highest $\mathrm{BaP}$ releases - each contributes to $4-5 \%$ of the Basin total. They are located in Illinois, Columbus, Indiana, and Ontario. It is believed that the source sectors in these areas such as iron \& steel industry, scrap tire burning, petroleum refining, and primary nonferrous metals production contributed significantly to the higher ambient BaP concentrations. This paper points to some directions on the possible data gaps on estimating $\mathrm{BaP}$ releases from non-point and mobile sources for both Canadian and U.S. inventories.

Local source contributes significantly to the elevated ambient air BaP concentrations. This explains why ambient $\mathrm{BaP}$ in urban is much higher than rural areas. The monitoring sites that are located in a grid cell representative of the local release are better indicators of the local BaP release and reduction trending. Therefore, monitoring sites should be properly selected to better indicate the local $\mathrm{BaP}$ reduction. There is no evidence of decreasing trend in most of the monitoring stations, such as in Toronto, Windsor, or Chicago. The reasons could be that there is no significant change of the local release regardless its release was high or low from the beginning. An exception is with Hamilton monitoring site. The station is located in the grid cell that is believed to be representative of the local $\mathrm{BaP}$ release. Its monitoring data show a declining trend of $\mathrm{BaP}$ in the ambient air in eight consecutive years from 1996-2003. It agrees very well with the declining trend of local $\mathrm{BaP}$ release due to the significant reduction of $\mathrm{BaP}$ from major source sectors in that area.

The monitoring data for the past 10-15 years show higher ambient air BaP are located in the areas with higher BaP releases. This is true for almost all the monitoring sites of IADN and NAPS with an exception with the Windsor/Detroit site, where a higher ambient air $\mathrm{BaP}\left(380 \mathrm{pg} / \mathrm{m}^{3}\right)$ is detected with a low annual release in less than $500 \mathrm{~kg} / \mathrm{y}$. This points to a need to further investigate both the air monitoring data and the $\mathrm{BaP}$ inventory. It is possible that some sources of $\mathrm{BaP}$ in Windsor/Detroit area were not well documented in the inventory.

\section{References}

[1] USEPA and Environment Canada. Great Lakes Binational Toxics Strategy. Co-chairs: Steve Rosenthal and Tom Tseng. www.binational.net.

[2] USEPA.2005. BaP inventory from 1999 NEI. The inventory spreadsheets were provided directly by USEPA.

[3] Environment Canada. 2006a. Mapping BaP Releases in the Great Lakes Basin. Volume III. Mapping and Analyses of BaP Releases in Ontario. Report prepared by EPOD-Ontario. March 2006.

[4] Source: U.S. Census Bureau, Population Estimates Program (website: http://www.census.gov/) and Statistics Canada (website: www.statcan.ca) both accessed on Feb 06, 2006 
[5] Source: U.S. Census Bureau, Population Estimates Program (website: http:/www.census.gov/) and Statistics Canada (website: www.statcan.ca) both accessed on Feb 06, 2006

[6] Environment Canada. 2006b. Mapping BaP Releases in the Great Lakes Basin. Volume II. Analyses of BaP Releases from State/Province in the Basin. Report prepared by EPOD-Ontario. March 2006.

[7] IADN 2006. International Air Deposition Network. March 2006. http://www.msc.ec.gc.ca/iadn

[8] EC 2006c. Annual Average BaP Concentrations for NAPS monitoring stations in Ontario. Excel spreadsheet, provided by Tom Dann of ETC, Environment Canada. February 2006.

[9] Blanchard, P. and Hulting, M. Personal Communications. Representatives for IADN on Canada and U.S. sites.

[10] EC 2006d. Ambient Air Measurements of Polycyclic Aromatic Hydrocarbons (PAH), PCDD, and PCDF in Canada (1987-1997). Report Series No. AAQD 98-3. Prepared by Tom Dann. Environmental Technology Center, Environment Canada. July 1998. 